\title{
LIVESTOCK IN THE SMALL FARMS OF SYSTEMS B AND C OF THE MAHAWELI PROJECT
}

\author{
A.B.P.A. BANDARA \\ Department of Animal Science, University of Peradeniya, Peradeniya.
}

(Date of receipt : 25 November 1991)

(Date of Acceptance : 27 August 1993)

\begin{abstract}
A field survey was conducted in Mahaweli Systems B and C with 128 farmers. Sheep, rabbits, ducks or fish were not available in the farms. $2 \%$ of farmers has goats and $<1 \%$ pigs. Greater than $28 \%$ of farmers were willing to raise goats, if provided good breeds. All the farmers were reluctant to raise pigs. Poultry were raised by $14 \%$ and $24 \%$ farmers in systems $B$ and $C$ respectively. The farmers expressed the need for a regular supply of chicks, veterinary care and the provision of incentives for higher poultry production.

About $82 \%$ farmers in system B and $29 \%$ in system C raised buffaloes, mainly for draught purpose, but were unwilling to expand their buffalo herds due to poor milk yields and difficulties in managing them in small holdings. Of farmers in system $C$, $81 \%$ raise cattle for both draught power and milk. Killari and Tharpakar were the most popular breeds for draught power and milk respectively. Only $30 \%$ farmers in system B raised cattle. However cattle are becoming more popular in both systems because of their milk yield, draught power and ease of tethering. The farmers express the need for good breeds and adequate grazing facilities for further development of their herds.
\end{abstract}

\section{INTRODUCTION}

Many farmers cultivate less than 10 hectares of land in Asia. These farms have a high labour input and low productivities. ${ }^{1}$ In planning improvements in livestock development a knowledge of currently available livestock in the farms is useful. This study investigated the farmers'willingness to raise different livestock species and their objectives in keeping livestock in the Mahaweli systems B and C areas. Mahaweli System B in the Dry Zone of Sri Lanka lies within the administrative districts of Polonnaruwa, Batticaloa and Amparai. ${ }^{2}$ The System C is located in the Dry-Intermediate Zone boundary including the districts of Badulla, Polonnaruwa and Amparai. ${ }^{3}$

\section{METHODS AND MATERIALS}

A field survey was conducted in systems B and C. The blocks where the settlement activities had been completed were selected. They were: Vijayabapura, Dimbulagala, Ellewewa and Dhamminna in System B and Bathalayaya, Hembarawa, Mendagama and Sandunpura in System C. Four units from each block and four farmers from each unit were chosen randomly. The total sample size was 128 farmers. The study was carried out during March to May 1988. The farmers were personally interviewed either at their home or in the field, on the following : types of livestock raised, breeds available and herd composition, productivities of livestock, willingness to raise or expand livestock 
production in the farm, and suggestions from farmers for better livestock production from their farms.

\section{RESULTS AND DISCUSSION}

Cattle and buffalo are the predominant livestock classes in systems B and C (Table 1). Considerable number of farmers raise poultry and few have goats and pigs. No farmer was found to have sheep, rabbit, duck or fish.

Table 1: Percentages of farmers raising livestock in Mahaweli Systems B and C.

\begin{tabular}{lcc}
\hline Livestock & System B & System C \\
\hline Cattle & 38 & 81 \\
Buffalo & 82 & 29 \\
Goats & 2 & 2 \\
Poultry & 24 & 14 \\
Pigs & 2 & 0 \\
\hline
\end{tabular}

\section{CATTLE}

Cattle in System B: The farmers in the system have less cattle compared to those in system $\mathrm{C}$ (Table 1). The main purpose of raising cattle is milk production. Hence the population of adult cows and bulls were $45 \%$ and $18 \%$ respectively (Table 2 ).

Tabel 2 : Herd composition of cattle in Mahaweli Systems B and C.

\begin{tabular}{lcc}
\hline Cattle type & \multicolumn{2}{c}{ Percentage } \\
& System B & System C \\
\hline Bulls & 18 & 45 \\
Cows & 45 & 29 \\
Calves & 37 & 26 \\
\hline
\end{tabular}

About $52 \%$ of cattle belonged to indigenous breeds (Table 3) with an average milk production of 1.5 litres per day (Table 4). The farmers are aware that raising indigenous cattle is less profitable, and therefore many farmers were reluctant to include those animals in their farms.

More than $90 \%$ of farmers were willing to raise better cattle if they were provided with high productive breeds and adequate grasslands. Effective programmes to distribute good breeds among the farmers are therefore essential. Alternative feeding 
programmes are: conservation of 7.2 tonnes of paddy straw annually, treating them with $4 \%$ urea and feeding three cattle at the rate of $7 \mathrm{~kg} /$ animal/day; planting $600 \mathrm{~m}$ long tree legume hedges at the highland and feeding them for animals daily at a rate of 3.5 $\mathrm{kg} /$ animal; feeding the small amount of highland crop residues whenever they become available; planting improved grasses and pasture legumes on the underutilized areas of the farm and practising stall feeding with such feeds. ${ }^{4}$

Table 3 : Livestock breeds found in Mahaweli Systems B and C.

\begin{tabular}{llcr}
\hline Livestock Species & Breed & System B\% & System C\% \\
\hline Cattle & Indigenous & 52.0 & 50.0 \\
& Bos indicus & 18.5 & 26.5 \\
& Crosses & 28.3 & 20.7 \\
& Bos taurus & 1.2 & 2.8 \\
Buffalo & Indigenous & 93.0 & 92.8 \\
& Murrah & 7.0 & 7.2 \\
Goats & Indigenous & 100.0 & 100.0 \\
Poultry & Indigenous & 35.6 & 63.6 \\
& R.I.R. crosses & 54.0 & 18.1 \\
& Leghorns & 10.4 & 9.1 \\
& New Hampshire & 0.0 & 9.2 \\
Pig & Crosses & 100.0 & 100.0 \\
\hline
\end{tabular}

Cattle in System C: Almost all the farmers were new settlers from Kandy and Nuwara-Eliya districts with previous experience in raising few cattle in small land holdings. Cattle raising may have become popular for this reason. More than $80 \%$ of livestock farmers in the area own cattle (Table 1). However farmers in system $\mathrm{C}$ raise cattle mainly for draught power. Hence $45 \%$ of cattle are bulls and only $29 \%$ are cows in this area (Table 2).

The Mahaweli Livestock Farm at Girandurukotte is the main livestock farm located in the system. This farm has initiated a programme to distribute on loan, draught bulls (mainly Killari) and dairy cows (mainly Tharpakar) to farmers. Since the tractors are expensive and the buffaloes are not readily available, many farmers benefit from this programme. The dairy cows distributed under this programme are relatively high productive, and many farmers tend to raise them for milk.

The farmers in this system are willing to raise both draught and dairy cattle and unlike in system B, they do not complain of the lack of good breeds. However the farmers stress the importance of having adequate grazing facilities. The feeding 
programme proposed for system B may be also introduced here to address this problem.

Table 4: Animal productivity in Mahaweli Systems B and C.

\begin{tabular}{llc}
\hline Livestock Species & Breed & Average productivity in two systems \\
\hline Cattle & Indigenous & 1.55 \\
& Bos indicus & 4.50 \\
& Crosses & 3.50 \\
& Bos taurus & 4.00 \\
Buffalo & Indigenous & 0.75 \\
Goats & Indigenous & 0.23 \\
Poultry & Average of & 17.00 \\
& all breeds & \\
\hline
\end{tabular}

- Cultle, buffaloes and goats-Litres of milk per animal per day.

- Poultry - Number of eggs per bird per month

\section{BUFFALOES}

Buffaloes in System B: Most of the farmers in this system are old settlers. The indigenous buffaloes are heavier than indigenous cattle ${ }^{5}$ and hence their draught power is greater. At present, $82 \%$ of farmers raise buffaloes primarily for land preparation and threshing, and very few get milk from their animals. More than $92 \%$ of the buffaloes belong to indigenous breeds (Table 3). These buffaloes give only about 0.75 litres of milk per day (Table 4). The farmers do not anticipate expanding the herd because it is difficult to tether these animals in smallholdings and poor milk production.

Buffaloes in System C: Buffaloes are less popular among the settlers in system C (Table 1), and the available ones are used for draught. The difficulties in managing buffaloes in smallholdings, and poor milk production were pointed out by the farmers.

Poultry: Although many farmers raised poultry (Table 1), in many instances this was not done systematically. One farmer in system $\mathrm{C}$ kept birds in cages and fed them on rice bran and commercial feeds, the others raised poultry under free range conditions. The birds were provided shelter for the night and are let out for scavenging during the day.

Broilers were not reared and few improved egg producing breeds were seen (Table 3). The indigenous breeds dominate and their monthly egg production is very poor (Table 4). Poor extension and veterinary services, the absence of a supply of good breeds, lack of commercial feeds and a poor market for poultry products are major constraints in the area. 
Goats and sheep: Farmers did not keep sheep and were unaware of sheep production. Only $2 \%$ farmers in each system had goats (Table 1). These were mainly indigenous breeds with poor milk production (Table 4). The goats were mainly raised for meat. However the farmers were reluctant to admit this on religious grounds. Damages to crops by browsing goats and the poor milk production are some of the factors that hinder goat husbandry. However, $>28 \%$ of farmers were willing to raise goats, if provided with good dual purpose breeds.

Pigs: Only one farmer in system B raised pigs and did so under a back yard system. Rice bran and kitchen refuse were the primary feed. $>98 \%$ farmers in the area are reluctant to raise pigs because they do not consider it socially respectable. Bad odour, unclean environment and religious taboo associated with raising pig may have caused this outlook.

Rabbits, ducks and fish: No farmer raised rabbits possibly due to prevailing religious attitudes. In the dry zone, it is difficult to maintain a pond or a small tank. This constraints raising ducks or fish. However the fresh water fish from reservoirs and village tanks are popular among the farmers.

\section{Acknowledgement}

I thank Prof. A.S.B. Rajaguru, Department of Animal Science, University of Peradeniya, and Dr F.R. Bolton of the Overseas Development Administration (ODA), for encouragement and the ODA for financial support.

\section{References}

1. Scoville O.J. Improving Ruminant Livestock Production on Small-Holdings. Seminar Report No. 11, (1976). The Agriculture Development Council Inc., New York, USA.

2. Acres International (1979). Maduru-Oya Project: Feasibility Report. Ministry of Mahaweli Development in Sri Lanka and Acres International Limited, Niagara Falls, Canada.

3. Hunting Technical Services (1979). System C Mahaweli Development Project: Feasibility Study, Main Report. Ministry of Mahaweli Development, Colombo, Sri Lanka and Hunting Technical Services Limited, Borehamwood, England.

4. Bandara A.B.P.A. \& Rajaguru A.S.B. (1990). An Alternative Livestock Feeding Programme for Mahaweli System B and C. Volume 2. Journal of the Postgraduate Institute of Agriculture, University of Peradeniya, Sri Lanka. pp. 23-32.

5. Siriwardena J.A. de S., Wickramasuriya U.G.J.S. \& Balachandran S.S. (1980). Management practices of buffalo in small farms. SAREC report of Workshop on water buffalo research in Sri Lanka. pp. 13-19. 